\title{
Quinoa: In Perspective of Global Challenges
}

\author{
Sirpaul Jaikishun ${ }^{1,2,3, *}$, Wenqiang $\mathrm{Li}^{1}{ }^{1}$, Zhenbiao Yang ${ }^{2,4, *}$ and Shikui Song ${ }^{2}$ \\ 1 Life Sciences College, Haixia Institute of Science and Technology, Fujian Agriculture and Forestry University, \\ Fuzhou 350002, China; liwenqiang_13895@126.com \\ 2 FAFU-UCR Center for Horticultural Biology and Metabolomics, Haixia Institute of Science and Technology, \\ Fujian Agriculture and Forestry University, Fuzhou 350002, China; shikui_song@163.com \\ 3 Department of Biology, Faculty of Natural Sciences, University of Guyana, Georgetown 413741, Guyana \\ 4 Institute of Integrative Genome Biology and Department of Botany and Plant Sciences, \\ University of California, Riverside, CA 90089, USA \\ * Correspondence: sirpaul.jaikishun@uog.edu.gy (S.J.); yang@ucr.edu (Z.Y.); \\ Tel.: +86-133-9591-0169 (S.J.); +86-131-2138-0559 (Z.Y.)
}

Received: 1 March 2019; Accepted: 3 April 2019; Published: 5 April 2019

\begin{abstract}
The global population is on the path of an increasing trajectory with a simultaneous decline in arable land resources through salinization and desertification that have resulted mainly from climate change and other anthropogenic activities. Rising temperatures will cause changes in the entire ecosystem, resulting in significant alterations in global climate paradigms and a threat to food security. This review focuses on how the highly resilient Chenopodium quinoa Willd. can sustainably mitigate some of the detrimental impacts, such as starvation, and support or provide ecosystem services. In comparison, compared with the traditional staple food crops, quinoa has remarkable tolerance to abiotic stresses and is highly nutritious, with a unique balance and higher amounts of nutrients, and can therefore be an important crop for food security and nutritional adequacy. This crop has the potential to ameliorate global challenges with respect to increase in global population, effects of climate change, desalinization, phytoremediation, satisfying nutrient deficiency, and alleviating poverty.
\end{abstract}

Keywords: global warming; nutrient composition; halophytes; desertification; salinization; phytoremediation

\section{Introduction}

The effects of global climate change and its influence on the growth and productivity of crop plants are poised to promulgate significant socioeconomic impacts on the global population and the environment. A warming climate will be unsuitable for plant growth and productivity, because it reduces the soil's potential to capture and retain water and maintain its fertility [1,2]. These effects will not only be detrimental to the environment, but will advance tremendous strain on the entire ecosystem due to the multifaceted origins and variable impacts. One of the major problems emanating from these scenarios is food security, which is poised to amplify progressively [3]. The global population is projected to be within the vicinity of 9.8 and 11.2 billion by 2050 and 2100, respectively, and it is necessary to provide adequate food with an increase in the current production within the agriculture sector. Notably, geographic areas with high percentage increases in population are already under severe strain in agriculture, impoverished, and highly susceptible to the effects of climate change (Figure 1) [4-7]. 


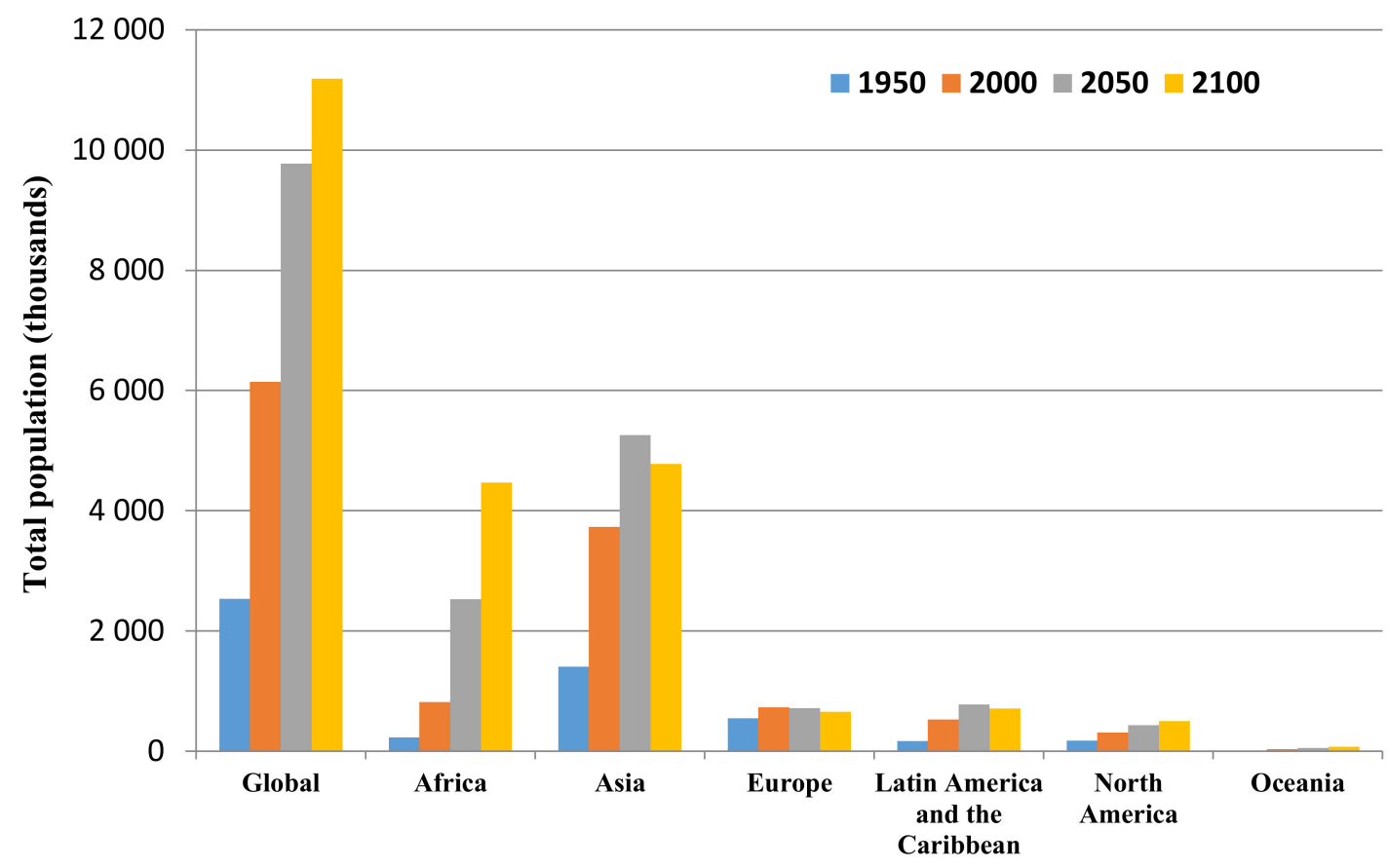

Figure 1. Total estimated global and different geographic area populations from 1950 and 2100 (Source: UN [7]).

Chenopodium quinoa Willd. is a pseudocereal and versatile crop with promising potential to meet the global food demand and reduce poverty in light of the population growth and the effects of global warming. It is regarded as a climate-change-resilient crop and originated from the Andean region, where it was cultivated and consumed by the Incas and Tiwankans for centuries until it was replaced by wheat as a primary food source. Quinoa is a gluten-free and highly nutritious seed crop with remarkable agronomic adaptations to different adverse climatic conditions, making it suitable for cultivating in countries that are susceptible to the effects of climate change. Quinoa adapts to and develops in the most extreme and unforgiving weather conditions, such as drought, high salinity, and frost $[8,9]$. With a great level of adaptability, quinoa can survive in lowlands, deserts, and areas over 4000 meters above sea level [10-14]. Since the declaration by United Nations that 2013 was the 'Year of the Quinoa' in recognition of its importance and nutritive quality, there has been a global thrust to increase production and, thus, many countries have initiated production or are in the phase of field evaluations for production $[8,11,13]$. It is a crop with the potential to become a sustainable food supply globally under rapidly changing climatic paradigm shifts while simultaneously ameliorating pressure on arable land [8]. Juxtaposing its resilience and nutritional benefits, quinoa, together with amaranth, has been described as "one of the grains of the 21st century" [15] that will play a key role in the provision of sustainable food in adverse environmental conditions resulting from climate change scenarios. For its credentials in nutritional composition and relevance, it was selected by NASA as a preferred food for its astronauts on board space missions [16]. This review endeavors to summarize the importance of quinoa as a sustainable food source and its versatility in response to global climatic changes and population growth.

\section{Historical and Cultural Perspective}

Quinoa originated from and remained an important food crop in the Andean regions, which encompass Bolivia, Peru, Ecuador, Colombia, Argentina, and Chile, an area aptly posited by Vavilov as one of the great centers for the origin of cultivated species [13,17]. It is a member of the Amaranthaceae family, along with spinach (Spinacia oleracea L.) and sugar beet (Beta vulgaris L.) as economically pertinent crops. It has been associated with the Incas and Tiwankans as a primary food 
for thousands of years before the first Spanish invasion. The Incas and Tiwankans had to defy the invaders' prohibition on quinoa production and consumption during the conquest when it was scorned as 'food for Indians' or for poor people and was not worthy to be consumed by elites. Quinoa did not fit within the realm of the European religious acceptance and preferential cuisine, and thus they proceeded to destroy the farms and severely penalized those who engaged in consumption and production of quinoa [18]. However, these incorrigible indigenous inhabitants preserved this crop by communal cultivation for centuries, which created an opportunity for in situ conservation of the germplasm $[19,20]$.

It is assumed that the closest ancestors of quinoa could originate from a single species, C. berlandieri var. nuttalliae Staff., with wide distribution in North America, or a multi-species origin that includes C. pallidicaule Aellen (Kañahua), C. petiolare Kunth, C. carnasolum Moq., and the tetraploid species, C. hircinum Schard. or C. quinoa var. Melanospermum growing in the southern hemisphere. All of these species have their origin in the Andean block, adding credence to the notion that they are close relatives of quinoa [21,22].

Jacobsen \& Mujic [11] noted that, within the southern Andean periphery, four species of Chenopodiums (C. carnosolum Moq., C. hircinum Schrad., C. incisum Poir. and C. petiolare Kunth) with close affinity to quinoa are deemed as its progenitors, which then morphed into modern day quinoa. Molecular, phylogenetic, and cytogenetic evidence indicated the allopolyploid origin of C. quinoa from the hybridization of diploid progenitors [23].

\section{Climate Resilience}

Quinoa has survived the rough terrain of the Andes for many thousands of years, with the capacity to grow in the highlands, valleys, and lowlands areas where the weather can be unforgiving and pose a threat to the existence of life. It has exceptional capacity to grow in water-deficient soil due to its inherent low water requirement and the ability to resume its photosynthetic rate and maintain its leaf area after a period of drought $[12,24,25]$. There is no doubt that the climate has been changing over the years, but with greater intensity and consequences in recent years. Global warming is making detrimental impacts on the agriculture system, the backbone of food security and the survival of a growing population. The direct effects of global warming include soil salinization, flooding, and drought, which will all lead to the massive degradation of vegetation and the soil structure [26]. Moreover, crops and vegetables will be severely impacted by heat stress, changes in the soil moisture, and evapotranspiration and by extreme weather patterns, including cyclones, floods and droughts, and salt water intrusion [26,27]. Saline water intrusion resulting from increasing sea levels in vulnerable coastal areas, extensive irrigation in arid regions, and persistent erosion are major contributors to increasing soil salinity, thereby limiting crop productivity and reducing arable land space. This will result in significant impacts on crop production and, therefore, pose serious threats to global food security and, more specifically, to countries that are directly affected by the effects of global warming. Quinoa stands at the pinnacle, with potential to confront these climatic changes and survive with substantial yields in these adverse conditions with its remarkable level of adaptations to these variations $[26,28,29]$. Quinoa can be categorized into the following five ecotype classifications: Highlands in Peru and Bolivia; Inter-Andean valleys in Colombia, Ecuador, and Peru; Salares in Bolivia, Chile, and Argentina; Yungas in Bolivia; and sea level in Chile. These wide ecological habitats may have been a contributing factor for such unique and remarkable adaptations [4,30,31]. Furthermore, Miranda et al. [32] assessed six varieties in three geographic areas with distinctive climatic and edaphic factors, and found that their seeds constitute adequate nutritional composition for human requirements (Table 1 and Figure 2) [32]. This further justifies the resiliency of quinoa to different climatic conditions which will eventually influence edaphic conditions, all of which are poised to change due to global warming. 
Table 1. Nutrient mineral of six quinoa varieties grown in three areas with distinct climatic and edaphic conditions. Data are expressed as g $100 \mathrm{~g}^{-1} \mathrm{DM}$ (dry mass). Values are expressed as mean \pm standard deviation (Source: Miranda et al. [32]).

\begin{tabular}{|c|c|c|c|c|c|c|}
\hline & \multicolumn{6}{|c|}{ Geographical Areas } \\
\hline & \multicolumn{2}{|c|}{ North } & \multicolumn{2}{|c|}{ Centre } & \multicolumn{2}{|c|}{ South } \\
\hline & Ancovinto & Cancosa & Cáhuil & Faro & Regalona & Villarrica \\
\hline $\mathrm{Ca}$ & $77.10 \pm 2.25$ & $105.01 \pm 4.56$ & $120.33 \pm 1.55$ & $121.39 \pm 3.74$ & $118.08 \pm 5.93$ & $211.29 \pm 0.35$ \\
\hline $\mathrm{Mg}$ & $152.31 \pm 0.44$ & $150.91 \pm 0.54$ & $160.55 \pm 0.72$ & $166.74 \pm 0.22$ & $155.77 \pm 1.36$ & $160.44 \pm 0.19$ \\
\hline $\mathrm{Na}$ & $<0.01 \pm 0$ & $<0.01 \pm 0$ & $18.46 \pm 11.68$ & $17.14 \pm 0.70$ & $19.58 \pm 3.19$ & $23.41 \pm 1.08$ \\
\hline $\mathrm{K}$ & $2188.54 \pm 0.67$ & $2325.56 \pm 12.22$ & $1672.79 \pm 0.56$ & $1774.43 \pm 11.89$ & $2038.42 \pm 10.88$ & $2243.99 \pm 37.49$ \\
\hline $\mathrm{Fe}$ & $6.91 \pm 0.31$ & $7.19 \pm 0.15$ & $5.06 \pm 0.03$ & $5.84 \pm 0.08$ & $7.03 \pm 0.26$ & $4.82 \pm 0.28$ \\
\hline $\mathrm{Cu}$ & $1.52 \pm 0.20$ & $0.75 \pm 0$ & $0.86 \pm 0.04$ & $0.89 \pm 0.02$ & $0.95 \pm 0.02$ & $0.89 \pm 0.02$ \\
\hline $\mathrm{Mn}$ & $2.39 \pm 0.02$ & $2.36 \pm 0.02$ & $6.47 \pm 0.17$ & $5.73 \pm 0.08$ & $4.67 \pm 0.15$ & $2.76 \pm 0.19$ \\
\hline $\mathrm{Zn}$ & $3.75 \pm 0.22$ & $3.10 \pm 0.03$ & $4.02 \pm 0.17$ & $2.73 \pm 0.01$ & $4.65 \pm 0.06$ & $5.01 \pm 0.38$ \\
\hline $\mathrm{P}$ & $526.36 \pm 3.79$ & $434.65 \pm 14.27$ & $409.92 \pm 8.42$ & $480.96 \pm 2.62$ & $353.53 \pm 10.88$ & $285.06 \pm 65.81$ \\
\hline
\end{tabular}

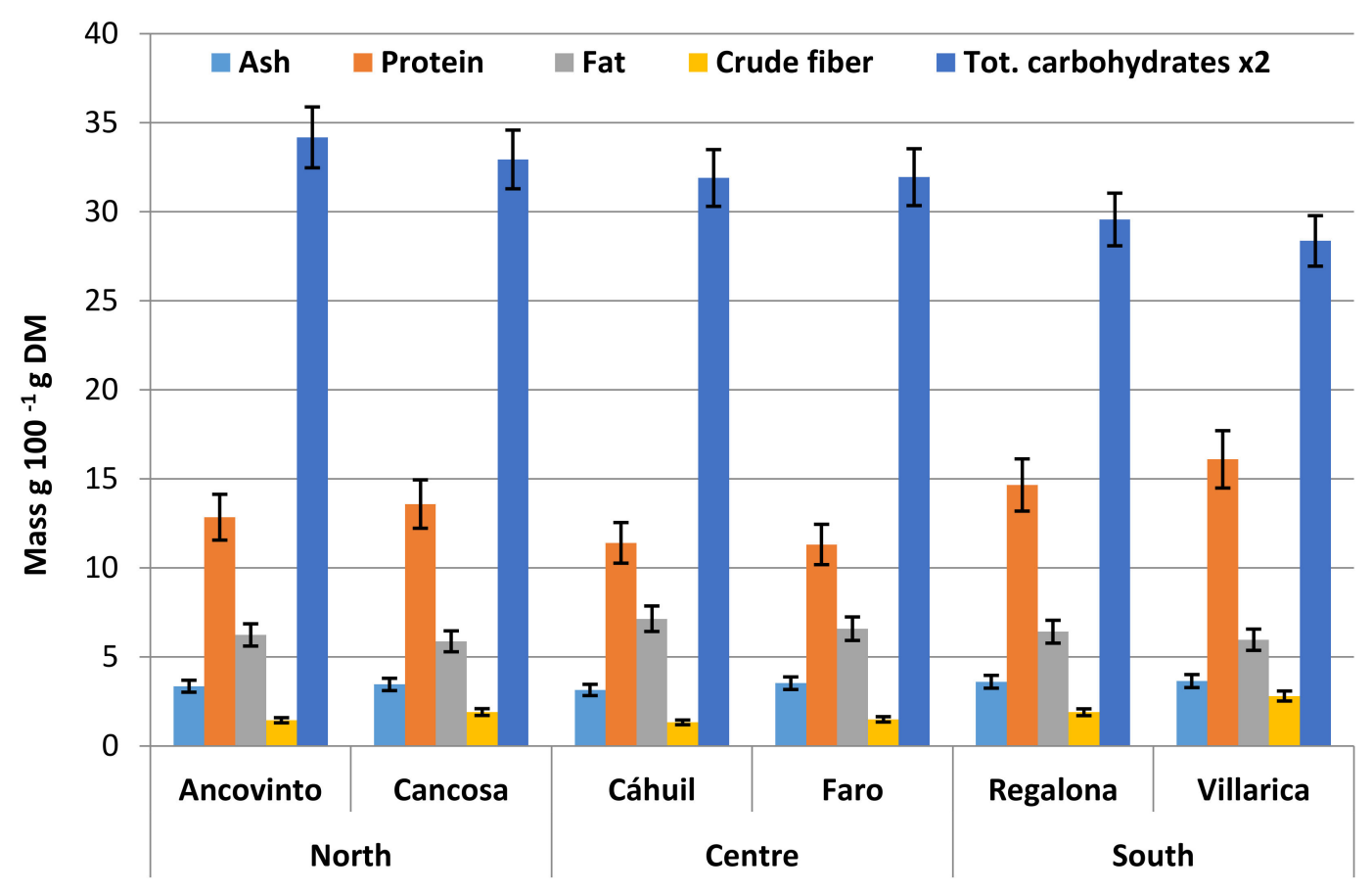

Figure 2. Nutrient content of six quinoa grown in three areas with distinct climatic and edaphic conditions. Data expressed as mean \pm standard deviation (Source: Miranda et al. [32]). DM, dry mass.

\subsection{Salinity Tolerance}

One of the effects of global warming is soil salinization and a reduction of fresh water resources. Quinoa is a facultative halophyte that belongs to the Amaranthaceae family, with approximately $40 \%$ of its genera possessing such potential, with approximately $1-2 \%$ of other known plant species. Halophytes are plants that grow and produce viable seeds at $\geq 200 \mathrm{mM} \mathrm{NaCl}$ concentrations, a variable that is lethal to $99 \%$ of other plants [33-36]. This strategically places quinoa in an advantageous position to glycophytes in that it can thrive in saline conditions because of its ability to avoid the severe impacts of high salt accumulation. Moreover, its ability to survive at salinity levels even higher than that of seawater makes it incomparable and more suitable than some other halophytes under such abiotic stress [37]. High salt concentrations in the soil or other growth media will cause hyperosmotic stress in roots and other structures. It decreases the plant's ability to efficiently absorb water because of osmotic stress and, once absorbed, the ionic constituents $\mathrm{Na}^{+}$and $\mathrm{Cl}^{-}$in the water adversely affect 
the metabolic activities and reduce the photosynthetic efficiency [34,38]. However, some plants have initiated the mechanisms to systematically deal with such an increase in salinity by mitigating osmotic stress through a reduction in water loss and optimizing water absorption [5]. Moreover, plants also minimize the toxicity of salt by exclusion from leaf tissues and the compartmentalization of $\mathrm{Na}^{+}$ into vacuoles, both internally and externally, in the case of salt bladders. These salt bladders have approximately between 200-to-1000-fold more volume space than that of epidermal cells and, hence, can potentially load and sequester more $\mathrm{Na}^{+}$than other cells and, consequently, plants without salt glands. Quinoa has the ability to exclude salts and to physiologically adjust them to minimize the effects of salts in high concentration [5,9,35,39-41]. The plant's response to these changes will determine their survival, growth, and development, together with the yield.

Many of the $\sim 6000$ global quinoa germplasm accessions that have been subjected to salt treatments, both in in situ and field experiments, and exhibited varying levels of tolerance during germination and progressive developmental phases [9,31,42-44]. Jacobsen et al. [13] observed that the quinoa yield was highest at 100 to $200 \mathrm{mM} \mathrm{NaCl}$, and thereafter decrease. Further support to this was provided by Hariadi et al. [10], who recorded significant inhibitory effects on seed germination at concentrations higher than $400 \mathrm{mM} \mathrm{NaCl}$, while optimal plant growth was obtained between 100 and $200 \mathrm{mM} \mathrm{NaCl}$ with 'Titicaca' over a 70-day growth period. Moreover, plants are referred to as halophytes based on their ability to grow and fully complete their life cycle, with seed production at $\geq 200 \mathrm{mM} \mathrm{NaCl}$ [35]. Gómez-Pando et al. [45] screened 182 quinoa accessions for salt tolerance and found that $25 \%$ of them exhibited greater than a $60 \%$ germination rate at $250 \mathrm{mM} \mathrm{NaCl}$ during a seven-day period. These 15 accessions were further tested in a pot experiment at 300 and $340 \mathrm{mM} \mathrm{NaCl}$. The results indicated that 13 accessions showed reduction in growth, while two grew 1.79 to $11 \%$ higher than the control. Some accessions can grow in salinity levels equivalent to sea water ( 400 to $500 \mathrm{mM} \mathrm{NaCl})$ [37,46]. Morales et al. [47] also observed that at $300 \mathrm{mM} \mathrm{NaCl}$, quinoa cultivars Chipaya and Ollague showed a decrease in fresh weight while at $450 \mathrm{mM} \mathrm{NaCl}$ they sustained a $50 \%$ and $40 \%$ higher transpiration rate than that of the control, respectively. Furthermore, Orsini et al. [48] outlined that an $\sim 50 \%$ reduction in stomatal density was observed at 600 and $700 \mathrm{mM} \mathrm{NaCl}$, with a decrease being identifiable in the stomatal number and density with increasing salinization on the adaxial and abaxial surfaces of the leaves. Increasing salt water intrusion compounded with events relating to climate change, such as increasing flooding due to more frequent and stronger storms, will increase soil salinization. Approximately $58 \%$ of the 1032 Mha of salt-affected soils is in irrigated areas [49]. It is estimated that $20 \%$ of irrigated cropland is affected by salinity, leading to a reduction in the yield and resulting in an estimated loss of USD 27.3 billion, globally [50]. Therefore, with quinoa having such tolerance to high levels of salinity, and in some cases, with concentrations even higher than that of sea water [48], it is necessary for quinoa production to be part of a global drive to meet the increasing demand for food while utilizing increasingly uninhabitable lands.

\subsection{Drought Tolerance}

Other harsh environmental conditions that are increasing as a result of climate change are drought and desertification, which are factors that negatively influence crop productivity worldwide [1,51-54]. Annually, human activity and climate change result in drying up of about 12 million hectares of productive land, thus transforming it into a barren state due to desertification and drought and causing more than one-third of the world's population to inhabit water-stressed areas [1,54]. Moreover, the population in drylands is expected to surge to about four billion by 2050, with South Asia adding more than 500 million people, and Central and South America and Sub-Saharan Africa doubling their population in these vulnerable areas (Figure 1) [1,3,52,55]. Furthermore, drought and climate change will impact soil quality and water sources. As with salinity, plants have evolved various morphological to physiological mechanisms to grow and develop in water-deficient environments. As is common with desert plants, crop and food plants are less known for such peculiar adaptations to water deficiency and arid environments. Plants respond to drought by adjusting physiological 
processes—-such as photosynthesis, respiration, water relations, and hormone metabolism—while they can also morphologically adjust through differential and strategic structural adjustment of its components [37,41,56,57].

Quinoa has an exceptional capacity to grow in water-deficient soil due to its inherent low water requirement and the ability to resume its photosynthetic rate and maintain its leaf area after a period of drought $[12,24,25]$. In the Andean region, drought can occur unpredictably with intermittent and terminal episodes, which can eventually lead to damage to seeds after sowing or the seedling stage, crop loss, and delayed harvest [12,58]. Quinoa responds to such stress through drought escape, tolerance, and avoidance $[11,58,59]$. Some other preventative mechanisms employed by quinoa include tissue elasticity, low osmotic potential, decreased leaf area through dehiscence, and the presence of vesicular calcium oxalate and structurally with small and think-walled cells $[12,19,25,60,61]$.

Garcia et al. [58] studied the stomatal response to water under irrigation and stressed conditions and observed that there was an $\sim 50 \%$ reduction in water potential in the stressed plants. Jensen et al. [25] examined the effects of desiccating soil on conductance, the photosynthetic rate, and the water relations of the quinoa leaf. They reported high net photosynthesis and specific leaf area in the early vegetative state while the low osmotic potential and turgid/dry weight ratios were observed in the later growth stage. Jacobsen et al. [12] followed up with a study on quinoa in drying soil and regulatory function of ABA (Abscisic acid) and posited that mild soil drying barely increased xylem ABA, while ABA produced in the root influenced stomatal function. Furthermore, they also concluded that soil drying resulted in stomatal closure, which affected the rate of photosynthesis.

The effect of drought on dry matter composition apportioning was studied by Gonzales et al. [18], who concluded that glucose and total soluble sugars were higher in quinoa under drought conditions, while other carbohydrates—such as fructose, sucrose, and starch — were differential, but no significant difference was identified. Proline content was also high in the plant tissues, as it is supposedly a biomarker of other stresses, such as cold salt, drought, temperature, and nutrient deprivation in plants [62-64]. These are premonitions that quinoa also has protective and defensive mechanisms to survive in water-deficient conditions, further adding the impetus to the need for its cultivation in vulnerable areas to bolster reclamation.

\subsection{Response to Temperature}

The Andean regions experience diverse climatic conditions, where a large area can be severely cold for an extended period, which holds the balance in the completion of the life cycle of quinoa, which is one of the few crops with the potential to tolerate some frosty conditions, with a special mechanism to prevent damage by low temperatures. They developed the mechanism to tolerate ice formation in the cell walls without irreversible damage to the cell structures and components [13,62-64]. Le Tacon et al. [65] reported that the temperatures on the Bolivian Altiplano ( $4000 \mathrm{~m})$ can be around $0{ }^{\circ} \mathrm{C}$, with sporadic freezing during the cropping and can be further decreased to subzero, resulting in frost formation, hence impacting the plant during the vegetative period. Bois et al. [66] mentioned that cold and frost have significant impacts from the onset of germination to other developmental stages, such as leaf appearance, water relations, biochemical changes, biomass, and portioning. Jacobsen et al. [13] concluded that quinoa survival at low temperatures is because of its high soluble sugar content, which may be a good indicator of frost tolerance in other plants as well. Quinoa has a high amount of soluble sugars, such as fructose and sucrose, with evidence of high levels of dehydrins. They also observed that two leaf seedlings exposed to $-4{ }^{\circ} \mathrm{C}$ for $4 \mathrm{~h}$ were slightly affected, and the yield was reduced by a mere $9 \%$ as opposed to those that grow at $9{ }^{\circ} \mathrm{C}$ while under the same condition at the 12-leaf stage, productivity decreased by over $50.7 \%$. These results suggested that the effects of low temperature are manifested in reduced productivity when quinoa plants are exposed at a later developmental stage, which is a clear indication that the sowing time is critical to achieve higher yields. Bois et al. [66] undertook research in exploring the effects of temperature on the germination and growth of 10 quinoa cultivars from the Andean Altiplano of Bolivia. Interestingly, they revealed that 
$90 \%$ of the cultivars were germinated at a subzero degree Celsius, further adding confidence that these cultivars are well adapted to very low temperatures, and the successive traits displayed significant varietal differences.

Yang et al. [67] experimented with quinoa being exposed to different water treatments and temperatures and observed higher values of stomatal conductance, leaf photosynthetic rate, efficiency of the photosynthetic system (PSII) and water use efficiency in high temperature conditions. All of these physiological responses are positive indications that quinoa has the potential to defy the effects of increasing temperature in some parts of the world. Moreover, some genotypes are known to inhabit areas with harsh dry and hot conditions in the Andean regions $[13,68]$. While the optimum temperature for quinoa's growth is within the range of 15 to $20^{\circ} \mathrm{C}$, some varieties still survive extremes of $-8^{\circ} \mathrm{C}$ and $38^{\circ} \mathrm{C}$, making them more ideal for increasingly changing climatic zones in many countries $[4,30]$.

\section{Botanical and Agronomic Features}

Quinoa displays extensive genetic diversity resulting from its adaptations to extreme environmental conditions associated with its ecotypes in the Andes $[4,8,9,13,31]$. Quinoa plants can reach between 0.3 and $3 \mathrm{~m}$ in height, having a wide range of colors (white, yellow, and pink, to darker red, purple, and black) and with thick, erect, woody stalk and taproot system. In early stages of development, its polymorphic leaves normally green and with maturity transcend to yellow, red, or purple. Seed diameter can range from $0.28-2.1 \mathrm{~cm}$, having two flat surfaces and rounded sides with colors ranging from black, red, pink, orange, yellow, or white [69-72]. Their survival in wide-ranging conditions allows them to be more growth conducive in different agroecological zones and yet exhibit appreciable yield [45,52]. Surprisingly, Gomez-Pando et al. [45] highlighted increased plant height, leaf dry mass, and yield in response to salinity. Additionally, Maliro et al. [73] found strong positive correlations between yield and plant height, maturity time, and biomass with irrigated system while significant differences in yield, plant biomass, and seed size among the genotypes under a rainfed system. Moreover, under irrigated conditions, seed yield was greater at Bunda (237-3019 kg/ha) than Bembeke (62-692 kg/ha). In support, Präger et al. [74] observed significant differences in seed weight between growing seasons and the varieties. Hence, different environmental conditions can contribute to differential results and hence, more trials and field evaluations must be employed repetitively to ascertain the most appropriate variety for specific conditions.

\section{Nutritional Importance}

According to the United Nations sectorial units on food and health, Food and Agricultural Organization and World Health Organization (FAO), quinoa is noted as the only plant food that constitutes and provides all of the essential amino acids required by the human body, with a higher protein content than that of rice, barley, corn, rye, and sorghum, but similar to that of wheat $[18,19,68,75-78]$. The invaluable source of nutrition of its seeds has also been identified through many studies that reveal high composition in carbohydrates, lipids, and high-quality proteins, with excellent balance and diversity, and has all of the essential amino acids [19,79-86]. FAO/World Health Organization/United Nations University (WHO/UNU) [87] outlined that quinoa protein can supply approximately $180 \%$ of histidine, $274 \%$ of isoleucine, $338 \%$ of lysine, $212 \%$ of methionine + cysteine, $320 \%$ of phenylalanine + tyrosine, $331 \%$ of threonine, $228 \%$ of tryptophan, and $323 \%$ of valine with respect to amino acids, which is more than recommended for adult nutritional requirements. Moreover, quinoa has 58-64\% carbohydrates in dry matter, with adequate amounts of glucose, fructose, saccharose, and maltose together with sufficient essential fatty acids. Additionally, quinoa has adequate amounts of protein, fat, ash, and carbohydrates as compared to rice, wheat, corn, oats, and barley (Figure 3) [77,87-89]. Once in bioavailable forms, calcium, magnesium, and potassium can satisfy nutritional adequacy in a balanced diet. However, removal of saponins may result in approximately $40 \%$ and $10 \%$ loss of calcium and phosphorus, respectively [16]. Quinoa is also rich in appreciable quantities of vitamins C, A, B1, B2, B3, B5, B7, E, folic acid, and carotene than those in rice, barley, and 
wheat $[77,82,90]$. Therefore, quinoa is an essential food for providing nourishment for the nearly 1 billion people who are undernourished and is equally essential for the same number of those who are obese, as it can be a healthy dietary choice. In addition, in 2013, approximately $15 \%$ of the world's children who are less than five years old have been considered to be malnourished, with approximately 50 million who are at risk of morbidity/mortality due to wasting away. Quinoa, with its rich and balanced nutrient composition, can provide adequate dietary consumption to alleviate some of these health conditions [3,54].

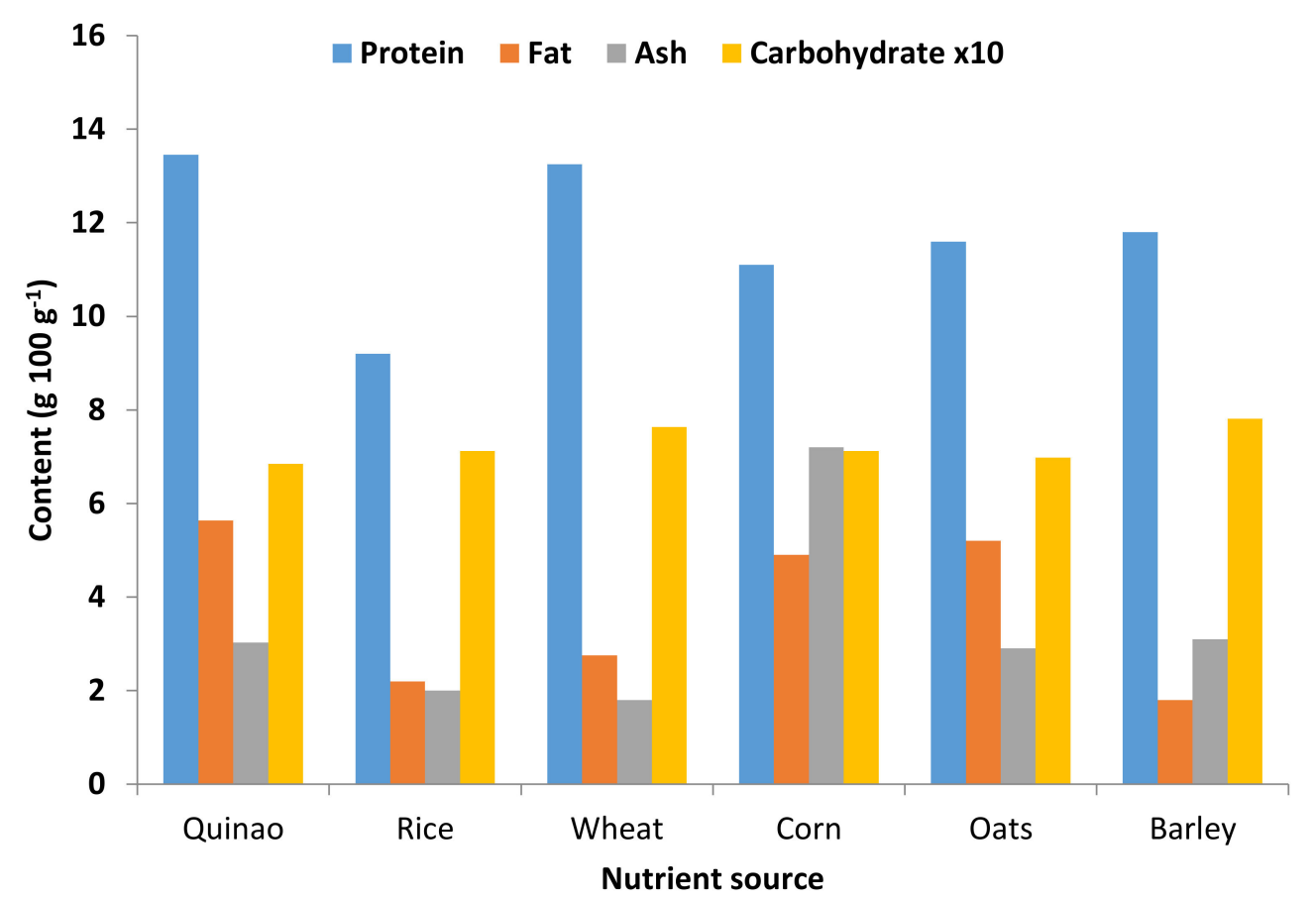

Figure 3. Proximate comparison nutrient composition of quinoa with other food sources (Sources: Repo-Currasco et al. [77]; FAO (Food and Agricultural Organization and World Health Organization) [87], Ahamed et al. [88] and Park et al. [89]).

\section{Ecosystem Functions}

The accumulation of salt in farm lands is becoming a very serious issue for crop production, as it limits the fundamental reason for such practice, productivity, and yield. Salinization plays an integral part in soil qualitative degradation, which lends to the undermining of food security $[1,10,91,92]$. Global climate change scenarios point in the direction of an increase in salinization and thus will have a significant impact on food security and sustainability in the near future $[1,10,54,91,92]$.

\subsection{Phytodesalinization}

Quinoa has the ability to extract more salt from the soil than that of many other halophytic plants through the accumulation of compatible organic solutes, succulence, and salt-secreting glands and bladders. The fact that they can survive under these saline conditions makes them suitable candidates for soil desalinization [93]. Salt bladders alone can sequester more salt due to the significant increase in volume it has as compared to the other epidermal cells $[40,94,95]$. Moreover, Hariadi et al. [10] determined that planting quinoa in soil premixed with $\mathrm{NaCl}$ with minimal leakage; over $50 \%$ of the salt was removed by the plants from the medium after a few months. This further suggests that quinoa can be an efficient method for desalinating soil in areas that are highly affected and can progressively pave the way for the cultivation of other salt-sensitive crops. While there is inadequate evidence available on quinoa being able to desalinate soils, other studies have already been exposed to such practice 
and have indeed yielded positive results $[96,97]$. Because of the lack of adequate information and publication in this area, more studies are encouraged to validate, ascertain, and assess the desalinating potential of different varieties of quinoa.

\subsection{Phytoremediation}

In addition to salt removal through phytodesalinization, quinoa, being halophytic, has the advantage and potential to remove heavy metals from the saline soil, which is uninhabitable to other less-salt-tolerant plants and glycophytes. The amount of soil contaminated with heavy metals is increasing due to population explosion, urbanization, industrialization, and other anthropogenic activities [52,98]. Halophytes have shown a higher tolerance to heavy metals and a greater rate of absorption from the soil and, with increasing mobility, promote the transference and translocation of heavy metals from soil to root and among other plant components [99-101]. Zulfiqar et al. [102] highlighted the effects and absorption level of cadmium (Cd) of C. album L. and C. murale L. While differential responses were observed, both species absorbed and sequestered $\mathrm{Cd}$ in their root and shoot and, hence, have been prescribed to be efficient phytoremediators of $\mathrm{Cd}$ in marginally contaminated soil with a minimal effect on the nutrient composition. Moreover, Bhargava et al. [98] assessed the accumulation efficiency of 40 accessions of Chenopodium spp. being subjected to iron (Fe), zinc ( $\mathrm{Zn})$, copper $(\mathrm{Cu})$, nickel $(\mathrm{Ni})$, chromium $(\mathrm{Cr})$, and cadmium $(\mathrm{Cd})$ and concluded that they all have the ability to accumulate a significant amount of metals in their leaves. Notably, C. quinoa had a higher accumulative potential of $\mathrm{Ni}, \mathrm{Cr}$, and $\mathrm{Cd}$, thus making them promising candidates as phytoremediators to detoxify contaminated soils. More interestingly, the majority of the 18 accessions of $C$. quinoa were deemed to be hyperaccumulators with a bioconcentration factor $>1$ for the six metals [55]. The results indicated that $\mathrm{Cd}$ had the highest bioconcentration factor (31), followed by $\mathrm{Fe}$ (30), $\mathrm{Cu}$ (19), $\mathrm{Ni}(5)$, $\mathrm{Zn}(3)$, and $\mathrm{Cr}$ (2) [52,98]. Haseeb et al. [103] undertook a study on four quinoa lines and observed that they have significant phytoextractive and hyper-accumulative potential. Interestingly, while the presence of $\mathrm{Pb}$ in different plant components inhibits some physiological function and yields, they alluded that the amount in the seeds is within the recommended safe limit [104] and, therefore, it does not pose a threat to human health. This incentivizes their role as a phytoremediator as well as being healthy for human consumption, while improving the soil health for successive food crops.

Moreover, the alarming rate of salinization and desertification of fertile land points to the grim reality that plant coverage and biodiversity will inevitably decrease due to habitat loss resulting from global warming, poor adherence to land management practices, and increasing industrialization combined with other anthropogenic activities [1]. Plant coverage decrease will eventually lead to a decrease in the overall conversion of carbon dioxide to oxygen through photosynthesis. Moreover, these factors may have significant impacts on biogeochemical processes, thereby inhibiting the cycling of nutrients and further influencing the build-up of greenhouse gases, thus contributing to global warming.

\section{Global Expansion}

Quinoa has been given global recognition as being a 'poor man's food' to an important crop for the future. Since quinoa was recognized by the United Nations for its great potential for health and its resilience to abiotic stresses, experimentation, and crop expansion continue across the globe [4]. In addition to planting, countries taking the initiative to employ breeding programs to develop varieties relative to their specific needs based on climatic conditions and preference. Concomitant with varietal development, some countries have engaged in the novel idea of sharing and exchanging germplasms with other countries to embark on crop experimentation and field evaluations with technical support from the FAO. These collaborative partnerships continue to enhance the expansion of quinoa crop production. Currently, there is a continuous drive in the cultivation of quinoa reaching over 95 countries, including Tibet, Morocco, France, India, China, the United Kingdom, Sweden, Denmark, Netherlands, and Italy $[4,30,105,106]$, with Guyana recently collaborating with the FAO in field evaluations (Figure 4). 
Hence, there is an increase in quinoa harvesting areas and production quantity post International Year of Quinoa (2013). Peru and Bolivia remained the principal global producers with 78,657 and 66,792 tonnes in 2017, representing 66 and $94 \%$ increases from 2013, respectively [107]. Some of these countries initiated cultivation many decades ago but are now refocusing on expansion since becoming privy to the positive attributes of quinoa.

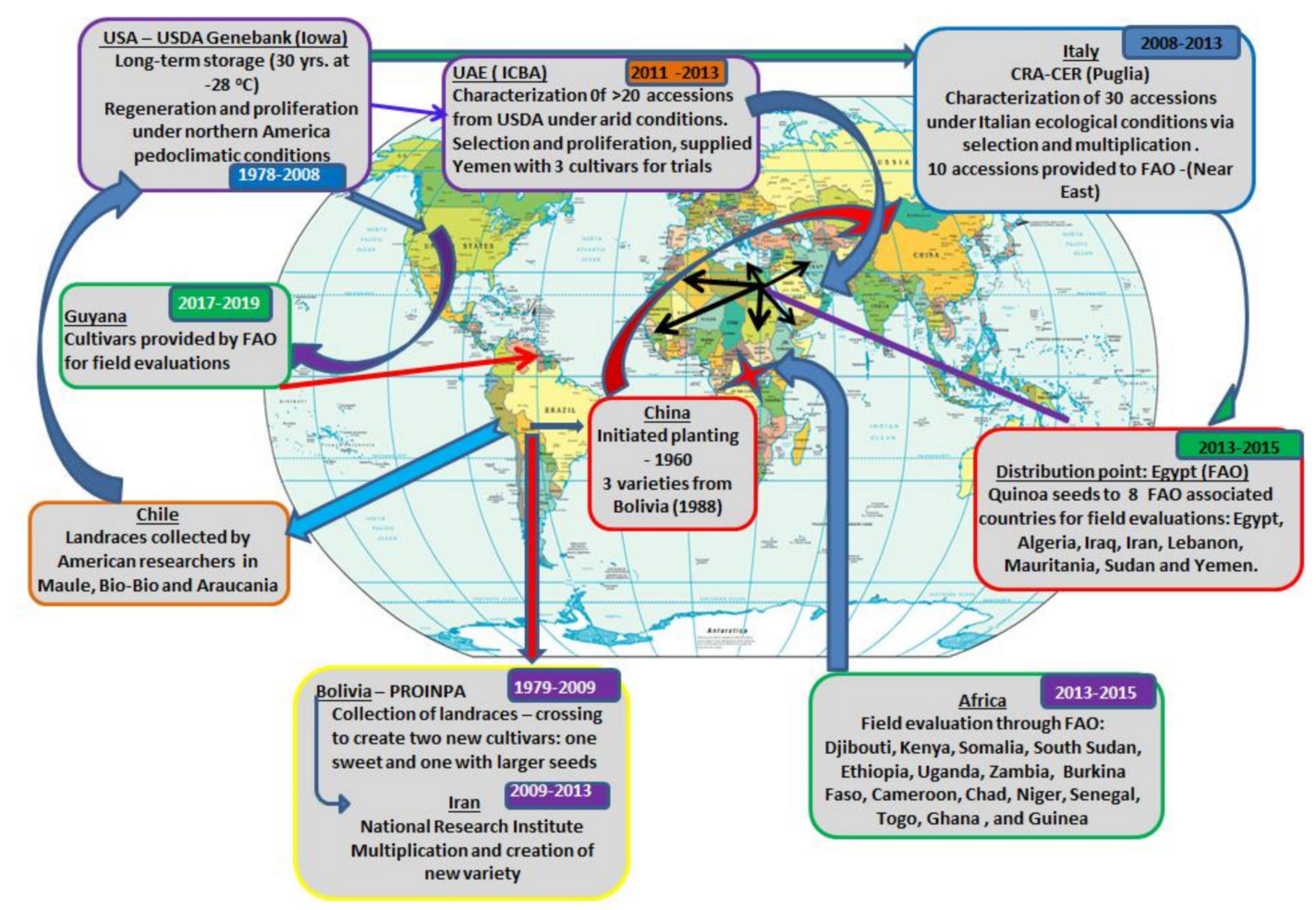

Figure 4. Global germplasm exchange, variety development and cultivation of quinoa from 1978 to 2017 (adopted and modified from: Bazile et al. [4] and Central Intelligence Agency (CIA) [108]).

\section{Future Perspective}

Although there has been a recent exponential increase in publications on quinoa in various thematic areas, greater emphasis should be placed on how the trait of rich nutrient composition of this crop can be transformed into other crops through genetic engineering to boost their nutrient status. This is more important now, with an aim to alleviate widespread hunger, since there is an eminent threat to food security and increasing levels of poverty.

More selective intraspecific breeding for desirable crop traits is imperative to combat the rising threat from climate change that makes plants more susceptible to rapidly changing and adverse environmental conditions. It should also reduce the varietal differences among them to improve adaptability and yield. A more in-depth analysis of the genetic nature of these unique adaptations of quinoa, along with their relevance to the development of crops with similar resilient potential, is essential to improve crop yield and quality. Quinoa is a crop that is superior to others in many aspects, such as its extraordinary adaptability to adverse weather conditions and its adequate nutritional composition, which make it the preferred choice to advance greater genetic manipulations.

More countries should be encouraged to commence quinoa cultivation, especially those with high vulnerability to climate change and food security. More experiments and field evaluations should be performed in areas that have been deemed uninhabitable due to abiotic stresses and other soil contaminants with of the aim of reclamation through phytodesalinization and phytoremediation. 
Based on the successes achieved in crop experimentation and implementation in many countries, other nations should be encouraged to initiate programs to facilitate quinoa growth and expansion with its potential to enhance socioeconomic status, improve health, and contribute to a safer environment.

Author Contributions: Conceptualization, S.J., and Z.Y.; writing-original draft preparation, S.J., S.S. and W.L.; writing-review and editing, S.J. and Z.Y.; supervision, Z.Y. and S.S.

Funding: This research received no external funding.

Conflicts of Interest: The authors declare no conflict of interest.

\section{References}

1. United Nations Convention to Combat Desertification. Policy Brief No. 3: Sustainable Land Management Solutions. Available online: http://catalogue.unccd.int/SER_SPIPB_3_ENG_WEB.pdf (accessed on 2 January 2019).

2. González, J.A.; Eisa, S.S.S.; Hussin, S.A.E.S.; Prado, F.E. Quinoa: An Incan crop to face global changes in agriculture. Quinoa Improv. Sustain. Prod. 2015, 1-18. [CrossRef]

3. Food and Agricultural Orgainisation of the United Nations (FAO); International Fund for Agricultural Development (IFAD); United Nations Children's Fund (UNICEF); World Food Programme (WFP); World Health Organization (WHO). The State of Food Security and Nutrition in the World 2018. Building Climate Resilience for Food Security and Nutrition; FAO: Rome, Italy, 2018; Available online: http: //www.fao.org/3/i9553en/i9553en.pdf (accessed on 1 January 2019).

4. Bazile, D.; Jacobsen, S.-E.; Verniau, A. The global expansion of quinoa: Trends and limits. Front. Sci. 2016, 7, 622. [CrossRef] [PubMed]

5. Deinlein, U.; Stephan, A.B.; Horie, T.; Luo, W.; Xu, G.; Schroeder, J.I. Plant salt-tolerance mechanisms. Trends Plant Sci. 2014, 19, 371-379. [CrossRef] [PubMed]

6. Flowers, T.J.; Muscolo, A. Introduction to the Special Issue: Halophytes in a changing world. AoB Plants 2015, 7. [CrossRef] [PubMed]

7. UN. Department of Economic and Social Affairs, Population Division. World Population Prospects: The 2017 Revision, Key Findings and Advance Tables. Working Paper No. ESA/P/WP/248. Available online: https://population.un.org/wpp/Publications/ (accessed on 2 January 2019).

8. Ruiz, K.B.; Biondi, S.; Martinez, E.A.; Orsini, F.; Antognoni, F.; Jacobsen, S.-E. Quinoa-A model crop for understanding salt-tolerance mechanisms in halophytes. Plant Biosyst. 2016, 150, 357-371. [CrossRef]

9. Ruiz, K.B.; Biondi, S.; Oses, R.; Acuña-Rodríguez, I.S.; Antognoni, F.; Martinez-Mosqueira, E.A.; Coulibaly, A.; Canahua-Murillo, A.; Pinto, M.; Zurita-Silva, A.; et al. Quinoa biodiversity and sustainability for food security under climate change. A review. Agron. Sustain. Dev. 2014, 34, 349-359. [CrossRef]

10. Hariadi, Y.; Marandon, K.; Tian, Y.; Jacobsen, S.-E.; Shabala, S. Ionic and osmotic relations in quinoa (Chenopodium quinoa Willd.) plants grown at various salinity levels. J. Exp. Bot. 2010, 62, 185-193. [CrossRef] [PubMed]

11. Jacobsen, S.; Mujica, A. The genetic resources of Andean grain amaranths (Amaranthus caudatus L., A. cruentus L. and A. hipochondriacus L.) in America. Plant Genet. Resour. Newsl. 2003, 133, 41-44.

12. Jacobsen, S.-E.; Liu, F.; Jensen, C.R. Does root-sourced ABA play a role for regulation of stomata under drought in quinoa (Chenopodium quinoa Willd.). Sci. Hortic. 2009, 122, 281-287. [CrossRef]

13. Jacobsen, S.E.; Mujica, A.; Jensen, C.R. The resistance of quinoa (Chenopodium quinoa Willd.) to adverse abiotic factors. Food Rev. Int. 2003, 19, 99-109. [CrossRef]

14. Maughan, P.J.; Turner, T.B.; Coleman, C.E.; Elzinga, D.B.; Jellen, E.N.; Morales, J.A.; Udall, J.A.; Fairbanks, D.J.; Bonifacio, A. Characterization of Salt Overly Sensitive 1 (SOS1) gene homoeologs in quinoa (Chenopodium quinoa Willd.). Genome 2009, 52, 647-657. [CrossRef] [PubMed]

15. Konishi, Y. Nutritional characteristics of pseudocereal amaranth and quinoa: Alternative foodstuff for patients with food allergy. J. Jpn. Soc. Nutr. Food Sci. 2002, 55, 299-302. [CrossRef]

16. Schlick, G.; Bubenheim, D.L. Quinoa: An Emerging New Crop with Potential for CELSS. Available online: https://ntrs.nasa.gov/archive/nasa/casi.ntrs.nasa.gov/19940015664.pdf (accessed on 21 September 2019).

17. Lescano, R.J.L. Genetics and Improvement of High Andean Crops: Quinoa, Kañihua, Tarwi, Kiwicha, Bitter Potato, Olluco, Mashua and Oca Programa Interinstitucional de Waru Waru; CIMA: Cieneguilla, Peru, 1994; pp. 459-561. 
18. Gonzalez, J.A.; Konishi, Y.; Bruno, M.; Valoy, M.; Prado, F.E. Interrelationships among seed yield, total protein and amino acid composition of ten quinoa (Chenopodium quinoa) cultivars from two different agroecological regions. J. Sci. Food Agric. 2012, 92, 1222-1229. [CrossRef]

19. Abugoch, L.; Castro, E.; Tapia, C.; Anon, M.C.; Gajardo, P.; Villarroel, A. Stability of quinoa flour proteins (Chenopodium quinoa Willd.) during storage. Int. J. Food Sci. Technol. 2009, 44, 2013-2020. [CrossRef]

20. Tapia, M. La Quinua: Historia, Distribución Geográfica, Actual Producción y Usos. Ambienta: La Revista del Ministerio de Medio Ambiente 2012, 99, 104-119. Available online: http://www.revistaambienta.es/ WebAmbienta/marm/Dinamicas/secciones (accessed on 21 January 2019).

21. Heiser, C.B.; Nelson, D.C. On the origin of the cultivated chenopods (Chenopodium). Genetics 1974, 78, 503-505.

22. Wilson, H.D.; Heiser, C.B., Jr. The origin and evolutionary relationships of 'huauzontle' (Chenopodium nuttalliae Safford), domesticated chenopod of Mexico. Am. J. Bot. 1979, 66, 198-206. [CrossRef]

23. Kolano, B.; McCann, J.; Orzechowska, M.; Siwinska, D.; Temsch, E.; Weiss-Schneeweiss, H. Molecular and cytogenetic evidence for an allotetraploid origin of Chenopodium quinoa and C. berlandieri (Amaranthaceae). Mol. Phylogenet. Evol. 2016, 100, 109-123. [CrossRef] [PubMed]

24. Galwey, N.; Leakey, C.L.A.; Price, K.R.; Fenwick, G.R. Chemical composition and nutritional characteristics of quinoa (Chenopodium quinoa Willd.). Food Sci. Nutr. 1989, 42, 245-261. [CrossRef]

25. Jensen, C.; Jacobsen, S.-E.; Andersen, M.; Andersen, S.; Mogensen, V.; Núñez, N.; Rasmussen, L. Leaf gas exchange and water relation characteristics of field quinoa (Chenopodium quinoa Willd.) during soil drying. Eur. J. Agron. 2000, 13, 11-25. [CrossRef]

26. Field, C.B.; Barros, V.R.; Dokken, D.; Mach, K.; Mastrandrea, M.; Bilir, T.; Chatterjee, M.; Ebi, K.L.; Estrada, Y.O.; Genova, R.C.; et al. IPCC 2014: Climate Change 2014: Impacts, Adaptation, and Vulnerability. Part A: Global and Sectoral Aspects. Contribution of Working Group II to the Fifth Assessment Report of the Intergovernmental Panel on Climate Change; Cambridge University Press: Cambridge, UK; New York, NY, USA, 2014; Available online: https://www.ipcc.ch/site/assets/uploads/2018/02/WGIIAR5 (accessed on 12 September 2018).

27. Metz, B.; Davidson, O.; De Coninck, H.; Loos, M.; Meyer, L. IPCC, 2005: IPCC Special Report on Carbon Dioxide Capture and Storage. Prepared by Working Group III of the Intergovernmental Panel on Climate Change. Available online: https://www.ipcc.ch/report/srccs (accessed on 1 January 2018).

28. IPCC. Impacts, Adaptation, and Vulnerability. Part A: Global and Sectoral Aspects. Contribution of Working Group II to the Fifth Assessment Report of the Intergovernmental Panel on Climate Change 2014. Available online: https://www.ipcc.ch/report/ar5/wg2 (accessed on 22 March 2019).

29. Panta, S.; Flowers, T.; Lane, P.; Doyle, R.; Haros, G.; Shabala, S. Halophyte agriculture: Success stories. Environ. Exp. Bot. 2014, 107, 71-83. [CrossRef]

30. Bazile, D.; Bertero, H.D.; Nieto, C. State of the Art Report on Quinoa Around the World in $2013 ; 2015$. Available online: http://www.fao.org/3/i4042e/I4042E.pdf (accessed on 21 November 2018).

31. Valencia-Chamorro, S. Quinoa. In Encyclopedia of Food Science and Nutrition; Caballero, B., Ed.; Academic Press: Amsterdam, The Nethelands, 2003; Volume 8, pp. 4895-4902.

32. Miranda, M.; Vega-Gálvez, A.; Quispe-Fuentes, I.; Rodríguez, M.J.; Maureira, H.; Martínez, E.A. Nutritional aspects of six quinoa (Chenopodium quinoa Willd.) ecotypes from three geographical areas of Chile. Chil. J. Agric. Res. 2012, 72, 175. [CrossRef]

33. Anjum, N.A.; Ahmad, I.; Válega, M.; Mohmood, I.; Gill, S.S.; Tuteja, N.; Duarte, A.C.; Pereira, E. Salt marsh halophyte services to metal-metalloid remediation: Assessment of the processes and underlying mechanisms. Crit. Rev. Environ. Sci. Technol. 2014, 44, 2038-2106. [CrossRef]

34. Flowers, T.; Yeo, A. Breeding for salinity resistance in crop plants: Where next? Funct. Plant Biol. 1995, 22, 875-884. [CrossRef]

35. Flowers, T.J.; Colmer, T.D. Salinity tolerance in halophytes. New Phytol. 2008, 179, 945-963. [CrossRef] [PubMed]

36. Glenn, E.P.; Anday, T.; Chaturvedi, R.; Martinez-Garcia, R.; Pearlstein, S.; Soliz, D.; Nelson, S.G.; Felger, R.S. Three halophytes for saline-water agriculture: An oilseed, a forage and a grain crop. Environ. Exp. Bot. 2013, 92, 110-121. [CrossRef]

37. Adolf, V.I.; Shabala, S.; Andersen, M.N.; Razzaghi, F.; Jacobsen, S.-E. Varietal differences of quinoa's tolerance to saline conditions. Plant Soil. 2012, 357, 117-129. [CrossRef] 
38. Mäser, P.; Eckelman, B.; Vaidyanathan, R.; Horie, T.; Fairbairn, D.J.; Kubo, M.; Yamagami, M.; Yamaguchi, K.; Nishimura, M.; Uozumi, N.; et al. Altered shoot/root Na+ distribution and bifurcating salt sensitivity in Arabidopsis by genetic disruption of the $\mathrm{Na}+$ transporter AtHKT1. FEBS Lett. 2002, 531, 157-161. [CrossRef]

39. Blumwald, E. Sodium transport and salt tolerance in plants. Curr. Opin. Cell Biol. 2000, 12, 431-434. [CrossRef]

40. Brownlee, C. Plant physiology: One way to dump salt. Curr. Biol. 2018, 28, R1145-R1147. [CrossRef]

41. Munns, R.; Tester, M. Mechanisms of salinity tolerance. Annu. Rev. Plant Biol. 2008, 59, 651-681. [CrossRef]

42. Christiansen, J.L.; Ruiz-Tapia, E.; Jørnsgård, B.; Jacobsen, S.-E. Fast Seed Germination of Quinoa (Chenopodium quinoa) at Low Temperature. Alternative Crops for Sustainable Agriculture: Research Progress: COST 814, Workshop, Turku, 1999; 29/01/2019. Available online: https://research. $\mathrm{ku} . \mathrm{dk} /$ search/?.../fast-seed-germination-of-quinoa (accessed on 29 January 2019).

43. Karyotis, T.; Iliadis, C.; Noulas, C.; Mitsibonas, T. Preliminary research on seed production and nutrient content for certain quinoa varieties in a saline-sodic soil. J. Agron. Crop Sci. 2003, 189, 402-408. [CrossRef]

44. Wilson, C.; Read, J.J.; Abo-Kassem, E. Effect of mixed-salt salinity on growth and ion relations of a quinoa and a wheat variety. J. Plant Nutr. 2002, 25, 2689-2704. [CrossRef]

45. Gomez-Pando, L.R.; Alvarez-Castro, R.; Eguiluz-de La Barra, A. Effect of salt stress on Peruvian Germplasm of Chenopodium quinoa Willd.: A promising crop. J. Agron. Crop Sci. 2010, 196, 391-396. [CrossRef]

46. Razzaghi, F.; Jacobsen, S.-E.; Jensen, C.R.; Andersen, M.N. Ionic and photosynthetic homeostasis in quinoa challenged by salinity and drought-Mechanisms of tolerance. Funct. Plant Biol. 2015, 42, 136-148. [CrossRef]

47. Morales, A.J.; Bajgain, P.; Garver, Z.; Maughan, P.J.; Udall, J.A. Physiological responses of Chenopodium quinoa to salt stress. Int. J. Plant Physiol. Biochem. 2011, 3, 219-232. [CrossRef]

48. Orsini, F.; Accorsi, M.; Gianquinto, G.; Dinelli, G.; Antognoni, F.; Carrasco, K.B.R.; Martinez, E.A.; Alnayef, M.; Marotti, I.; Bosi, S.; et al. Beyond the ionic and osmotic response to salinity in Chenopodium quinoa: Functional elements of successful halophytism. Funct. Plant Biol. 2011, 38, 818-831. [CrossRef]

49. Metternicht, G.I.; Zinck, J.A. Remote sensing of soil salinity: Potentials and constraints. Remote Sens. Environ. 2003, 85, 1-20. [CrossRef]

50. Qadir, M.; Quillerou, E.; Nangia, V.; Murtaza, G.; Singh, M.; Thomas, R.; Drechsel, P.; Noble, A. Economics of salt-induced land degradation and restoration. Nat. Resour. Forum 2014, 38, 282-295. [CrossRef]

51. Barrera-Figueroa, B.; Gao, L.; Diop, N.N.; Wu, Z.; Ehlers, J.D.; A Roberts, P.; Close, T.J.; Zhu, J.-K.; Liu, R. Identification and comparative analysis of drought-associated microRNAs in two cowpea genotypes. BMC Plant Biol. 2011, 11, 127. [CrossRef]

52. Bhargava, A.; Srivastava, S. Quinoa: Botany, Production and Uses; CABI: Wallingford, UK, 2013.

53. Raney, J.A. Transcriptome analysis of drought induced stress in Chenopodium quinoa. Am. J. Plant Sci. 2012, 5, 338-357. [CrossRef]

54. UNCCD. Global Land Outlook. UN Convention to Combat Desertification Bonn. Available online: https://www.unccd.int/actions/global-land-outlook-glo (accessed on 2 January 2019).

55. Bhargava, A.; Carmona, F.F.; Bhargava, M.; Srivastava, S. Approaches for enhanced phytoextraction of heavy metals. J. Environ. Manag. 2012, 105, 103-120. [CrossRef] [PubMed]

56. Andrés, A.-S.; Sven-Erik, J.; Fatemeh, R.; Ricardo, A.-F. Quinoa Drought Responses and Adaptation. Available online: http://www.fao.org/3/i4042e/I4042E.pdf (accessed on 21 November 2018).

57. Mahajan, S.; Tuteja, N. Cold, salinity and drought stresses: An overview. Arch. Biochem. Biophys. 2005, 444, 139-158. [CrossRef] [PubMed]

58. Garcia, M.; Raes, D.; Jacobsen, S.E.; Michel, T. Agroclimatic constraints for rainfed agriculture in the Bolivian Altiplano. J. Arid Environ. 2007, 71, 109-121. [CrossRef]

59. Jacobsen, S.E.; Quispe, H.; Mujica, A. Quinoa: An Alternative Crop for Saline Soils in the Andes, Scientists and Farmer-Partners in Research for the 21st Century; CIP: Miraflores, Peru, 1999.

60. Canahua, A. Observaciones del comportamiento de la quinua a la sequía. In Primer Congreso Internacional Sobre Cultivos Andinos; Universidad Nacional San Cristobal de Huamanga, Instituto Interamericano de Ciencias Agricolas: Ayacucho, Peru, 1977; pp. 390-392.

61. Garcia, M. Agroclimatic Study and Drought Resistance Analysis of Quinoa for An Irrigation Strategy in the Bolivian Altiplano. Dissertationes de Agricultura 556; KU Leuven: Leuven, Belgium, 2003.

62. Naik, G.; Joshi, G. Ineffectual role of proline metabolism in salt-stressed sugarcane leaves. Proc. Plant Sci. 1983, 92, 265-269. [CrossRef] 
63. Siddiqu, S.; Krishnamoorthy, H. Effect of B-nine on the proline content of gram (Cicer arietinum) under saline conditions. Indian J. Plant Physiol. 1987, 1, 107-110.

64. Vera-Hernández, P.; Ramírez, M.; Núñez, M.; Ruiz-Rivas, M.; Rosas-Cárdenas, F. Proline as a probable biomarker of cold stress tolerance in Sorghum (Sorghum bicolor). Mex. J. Biotechnol. 2018, 3, 77-86. [CrossRef]

65. Le Tacon, P.; Vacher, J.; Eldin, M.; Imaña, E. Los Riesgos de Helada en el Altiplano Boliviano. ORSTOM/IBTA La Paz. Available online: http://horizon.documentation.ird.fr/exl-doc/pleins_textes/divers09-11/38556.pdf (accessed on 21 September 2018).

66. Bois, J.E.; Winkel, T.; Lhomme, J.P.; Raffaillac, J.P.; Rocheteau, A. Response of some Andean cultivars of quinoa (Chenopodium quinoa Willd.) to temperature: Effects on germination, phenology, growth and freezing. Eur. J. Agron. 2006, 25, 299-308. [CrossRef]

67. Yang, A.; Akhtar, S.S.; Amjad, M.; Iqbal, S.; Jacobsen, S.E. Growth and physiological responses of quinoa to drought and temperature stress. J. Agron. Crop Sci. 2016, 202, 445-453. [CrossRef]

68. Aloisi, I.; Parrotta, L.; Ruiz, K.B.; Landi, C.; Bini, L.; Cai, G.; Biondi, S.; Del Duca, S. New insight into quinoa seed quality under salinity: Changes in proteomic and amino acid profiles, phenolic content, and antioxidant activity of protein extracts. Front. Plant Sci. 2016, 7, 656. [CrossRef] [PubMed]

69. Oelke, E.; Putnam, D.; Teynor, T.; Oplinger, E. Quinoa. Alternative Field Crops Manual. University of Wisconsin Cooperative Extension Service, University of Minnesota Extension Service. Available online: https://hort.purdue.edu/newcrop/afcm/quinoa.html (accessed on 24 March 2019).

70. Jacobsen, S.-E.; Stølen, O. Quinoa-morphology, phenology and prospects for its production as a new crop in Europe. Eur. J. Agron. 1993, 2, 19-29. [CrossRef]

71. Bhargava, A.; Shukla, S.; Rajan, S.; Ohri, D. Genetic diversity for morphological and quality traits in quinoa (Chenopodium quinoa Willd.) germplasm. Genet. Resour. Crop Evol. 2007, 54, 167-173. [CrossRef]

72. Sosa-Zuniga, V.; Brito, V.; Fuentes, F.; Steinfort, U. Phenological growth stages of quinoa (Chenopodium quinoa) based on the BBCH scale. Ann. Appl. Biol. 2017, 171, 117-124. [CrossRef]

73. Maliro, M.F.A.; Guwela, V.F.; Nyaika, J.; Murphy, K.M. Preliminary studies of the performance of quinoa (Chenopodium quinoa Willd.) genotypes under irrigated and rainfed conditions of Central Malawi. Front. Plant Sci. 2017, 8, 227. [CrossRef] [PubMed]

74. Präger, A.; Munz, S.; Nkebiwe, P.M.; Mast, B.; Graeff-Hönninger, S. Yield and quality characteristics of different quinoa (Chenopodium quinoa Willd.) cultivars grown under field conditions in southwestern Germany. Agronomy 2018, 8, 197. [CrossRef]

75. Escuredo, O.; Martin, M.I.G.; Moncada, G.W.; Fischer, S.; Hierro, J.M.H. Amino acid profile of the quinoa (Chenopodium quinoa Willd.) using near infrared spectroscopy and chemometric techniques. J. Cereal Sci. 2014, 60, 67-74. [CrossRef]

76. Filho, A.M.; Pirozi, M.R.; Borges, J.T.; Pinheiro Sant'Ana, H.M.; Chaves, J.B.; Coimbra, J.S. Quinoa: Nutritional, functional, and antinutritional aspects. Crit. Rev. Food Sci. Nutr. 2017, 57, 1618-1630. [CrossRef] [PubMed]

77. Repo-Carrasco, R.; Espinoza, C.; Jacobsen, S.-E. Nutritional value and use of the Andean crops quinoa (Chenopodium quinoa) and kañiwa (Chenopodium pallidicaule). Food Rev. Int. 2003, 19, 179-189. [CrossRef]

78. USDA. National Nutrient Database for Standard Reference, Release 28. Available online: https://ndb.nal. usda.gov/ndb/ (accessed on 2 January 2019).

79. Aluko, R.E.; Monu, E. Functional and bioactive properties of quinoa seed protein hydrolysates. J. Food Sci. 2003, 68, 1254-1258. [CrossRef]

80. Caperuto, L.C.; Amaya-Farfan, J.; Camargo, C.R.O. Performance of quinoa (Chenopodium quinoa Willd) flour in the manufacture of gluten-free spaghetti. J. Sci. Food Agric. 2001, 81, 95-101. [CrossRef]

81. Mastebroek, H.D.; Limburg, H.; Gilles, T.; Marvin, H.J.P. Occurrence of sapogenins in leaves and seeds of quinoa (Chenopodium quinoa Willd). J. Sci. Food Agric. 2000, 80, 152-156. [CrossRef]

82. Ruales, J.; Nair, B.M. Nutritional quality of the protein in quinoa (Chenopodium quinoa, Willd) seeds. Plant Foods Hum. Nutr. 1992, 42, 1-11. [CrossRef] [PubMed]

83. Wood, S.; Lawson, L.; Fairbanks, D.J.; Robison, L.; Andersen, W. Seed lipid content and fatty acid composition of three quinoa cultivars. J. Food Compos. Anal. 1993, 6, 41-44. [CrossRef]

84. Wright, K.H.; Huber, K.C.; Fairbanks, D.J.; Huber, C.S. Isolation and characterization of Atriplex hortensis and sweet Chenopodium quinoa starches. Cereal Chem. 2002, 79, 715-719. [CrossRef]

85. Wright, K.H.; Pike, O.A.; Fairbanks, D.J.; Huber, C.S. Composition of Atriplex hortensis, sweet and bitter Chenopodium quinoa seeds. J. Food Sci. 2002, 67, 1383-1385. [CrossRef] 
86. Zhu, J.K. Plant salt tolerance. Trends Plant Sci. 2001, 6, 66-71. [CrossRef]

87. FAO/WHO/UNU. Energy and Protein Requirements: Report of a Joint FAO/WHO/UNU Expert Consultation. WHO. Report No.: 9241207248. Available online: https://www.ncbi.nlm.nih.gov/pubmed/3937340 (accessed on 19 December 2017).

88. Ahamed, N.T.; Singhal, R.S.; Kulkarni, P.R.; Pal, M. A lesser-known grain, Chenopodium quinoa: Review of the chemical composition of its edible parts. Food Nutr. Bull. 1998, 19, 61-70. [CrossRef]

89. Park, J.H.; Lee, Y.J.; Kim, Y.H.; Yoon, K.S. Antioxidant and antimicrobial activities of quinoa (Chenopodium quinoa Willd.) seeds cultivated in Korea. Prev. Nutr. Food Sci. 2017, 22, 195. [CrossRef]

90. Kozioł, M. Chemical composition and nutritional evaluation of quinoa (Chenopodium quinoa Willd.). J. Food Compos. Anal. 1992, 5, 35-68. [CrossRef]

91. Halford, N.G.; Curtis, T.Y.; Chen, Z.; Huang, J. Effects of abiotic stress and crop management on cereal grain composition: Implications for food quality and safety. J. Exp. Bot. 2015, 66, 1145-1156. [CrossRef]

92. Mickelbart, M.V.; Hasegawa, P.M.; Bailey-Serres, J. Genetic mechanisms of abiotic stress tolerance that translate to crop yield stability. Nat. Rev. Genet. 2015, 16, 237-251. [CrossRef]

93. Song, J.; Wang, B. Using euhalophytes to understand salt tolerance and to develop saline agriculture: Suaeda salsa as a promising model. Ann. Bot. 2014, 115, 541-553. [CrossRef] [PubMed]

94. Shabala, S. Learning from halophytes: Physiological basis and strategies to improve abiotic stress tolerance in crops. Ann. Bot. 2013, 112, 1209-1221. [CrossRef] [PubMed]

95. Shabala, S.; Bose, J.; Hedrich, R. Salt bladders: Do they matter? Trends Plant Sci. 2014, 19, 687-691. [CrossRef] [PubMed]

96. Ado, M.N.; Guero, Y.; Michot, D.; Soubeiga, B.; Kiesse, T.S.; Walter, C. Phytodesalinization of irrigated saline Vertisols in the Niger Valley by Echinochloa stagnina. Agric. Water Manag. 2016, 177, 229-240. [CrossRef]

97. Zorrig, W.; Rabhi, M.; Ferchichi, S.; Smaoui, A.; Abdelly, C. Phytodesalination: A solution for salt-affected soils in arid and semi-arid regions. J. Arid Land Stud. 2012, 22, 299-302.

98. Bhargava, A.; Shukla, S.; Srivastava, J.; Singh, N.; Ohri, D. Chenopodium: A prospective plant for phytoextraction. Acta Physiol. Plant. 2008, 30, 111-120. [CrossRef]

99. Flowers, T.J.; Galal, H.K.; Bromham, L. Evolution of halophytes: Multiple origins of salt tolerance in land plants. Funct. Plant Biol. 2010, 37, 604-612. [CrossRef]

100. Taamalli, M.; Ghabriche, R.; Amari, T.; Mnasri, M.; Zolla, L.; Lutts, S.; Abdely, C.; Ghnaya, T. Comparative study of $\mathrm{Cd}$ tolerance and accumulation potential between Cakile maritima L. (halophyte) and Brassica juncea $\mathrm{L}$. Ecol. Eng. 2014, 71, 623-627. [CrossRef]

101. Wang, H.-L.; Tian, C.-Y.; Jiang, L.; Wang, L. Remediation of heavy metals contaminated saline soils: A halophyte choice? Environ. Sci. Technol. 2013, 48, 21-22. [CrossRef]

102. Zulfqar, S.; Wahid, A.; Farooq, M.; Maqbool, N.; Arfan, M. Phytoremediation of soil cadmium using Chenopodium species. Pak. J. Agric. Sci. 2012, 49, 435-445.

103. Haseeb, M.; Basra, S.M.A.; Afzal, I.; Wahid, A. Quinoa response to lead: Growth and lead partitioning. Int. J. Agric. Biol. 2018, 20, 338-344. [CrossRef]

104. FAO/WHO. Codex Alimentarius Commission. Food Additives and Contaminants. Joint FAO. Available online: www.fao.org/input/download/report/17/a19112ae.pdf (accessed on 11 February 2016).

105. Bhargava, A.; Shukla, S.; Ohri, D. Chenopodium quinoa-An Indian perspective. Ind. Crops Prod. 2006, 23, 73-87. [CrossRef]

106. Pulvento, C.; Riccardi, M.; Lavini, A.; Iafelice, G.; Marconi, E.; d'Andria, R. Yield and quality characteristics of quinoa grown in open field under different saline and non-saline irrigation regimes. J. Agron. Crop Sci. 2012, 198, 254-263. [CrossRef]

107. Food and Agricultural Organisation of the United Nations Statitics (FAOSTAT). Food and Agricultural Data. 2017. Available online: http://www.fao.org/faostat/en (accessed on 30 March 2019).

108. CIA. The World Factbook 2012-13. Central Intelligence Agency. Report No.: 0160911427. Available online: https://geology.com/world/cia-world-map.gif (accessed on 29 March 2019).

(C) 2019 by the authors. Licensee MDPI, Basel, Switzerland. This article is an open access article distributed under the terms and conditions of the Creative Commons Attribution (CC BY) license (http://creativecommons.org/licenses/by/4.0/). 